\title{
ERRORS IN NARRATIVE TEXT COMMITTED BY STUDENTS IN GRADE XI OF VOCATIONAL HIGH SCHOOL (SMK) STATE 4 SURAKARTA
}

\author{
Eko Mulyono \\ ekomulyono588@gmail.com
}

Muhammadiyah University of Surakarta

\begin{abstract}
This study aimes to identify the types of errors in the students' writing, to know the frequencies of each type of errors, and to investigate the causes of errors. There are three types of errors occured in the students' writing namely lexical error, syntactical error, and discourse error. The errors can be categorized into twenty four subcategories of errors: wrong spelling words $(10,35 \%)$, wrong selection words $(15,53 \%)$, omission verb $(0,74 \%)$, omission v-ing after preposition for $(0,55 \%)$, addition unnecessary verb $(0,74 \%)$, using simple present tense refers to simple past $(22,37 \%)$, use simple future instead of past future $(2,40 \%)$, using irregular past verb tense after to infinitive $(2,40 \%)$, addition final ed after to infinitive $(1,85 \%)$, addition $\mathrm{v}$-ing after to infinitive $(1,11 \%)$, addition double marking verb $(1,66 \%)$, omission to be $(11,65 \%)$, addition to be $(1,29 \%)$, omission s/es in the use of plural noun $(2,40 \%)$, addition $\mathrm{s}$ in singular noun $(1,29 \%)$, omission article $(6,47 \%)$, addition unnecessary article $(1,66 \%)$, wrong article $(1,11 \%)$, wrong subject pronoun $(2,03 \%)$, wrong object pronoun $(0,55 \%)$, wrong possessive pronoun $(2,03 \%)$, generic structure $(2,96 \%)$, reference $(2,03 \%)$, wrong selection conjunction $(4,81 \%)$. The most dominant error is in syntactical error i.e. using simple present tense refers to simple past with the percentage $22,37 \%$. Those errors are caused by four aspects, they are overgeneralization, incomplete application of rules, ignorance of rule restrictions, and false concept hypothesized.
\end{abstract}

Keywords: error analysis, causes of errors, interlanguage, grammar, writing

Errors in language learning are natural. Moreover, when the teachers teach in the school, they will find many phenomena; they will find many students who have good writing in English, many students who have middle writing, and may be they will find many students who have low ability in writing English.Vocational students use English as the foreign language, English subject is compulsory in the curriculum 2013 and one of the subject that students must 
learn is writing. As the students learn more about English, many errors will appear. Not only they replace one tense with the other tense(s), but also they fail to construct the correct verb forms for these tenses. They often commit the error in their writing production. Based on pre-observation result, the researcher asked the students of vocational high school to make narrative text. Below are the examples of student's writing products:

One day in [...] village lived [...] happy family, but everyting changes when mother past away and father Kirana married with Sulastri, this is start bad Kirana.

Sulastri gave neakle to Kirana, Kirana so funny after Kirana use neakle Kirana tunn into golden slug and to throw away in [...] river.

The example above showed that students committed errors toward their writing because they lack of English grammatical rule. To cope with these, they often relied on the linguistic knowledge they already knew either from their first language (L1) or the target language (L2). The example in the first paragraph, One day in [...] village lived [...] happy family, but everyting changes when mother past away and father Kirana married with Sulastri, this is start bad Kirana. This sentence misses the use of article $a$ before the subject, wrong spelling everyting should be everything, wrong selection words past away should be passed away, and start bad Kirana to be Kirana's life, misordering father Kirana should be Kirana's father, it means that they lack of the grammatical rule. Then the example in the second paragraph, Sulastri gave neakle to Kirana, Kirana so funny after Kirana use neakle Kirana tunn into golden slug and to throw away in [...] river. It means that student commits error in wrong spelling words neakle instead of necklace, tunn instead of turned and wrong in selection word slug instead of snail, and also omits the use of article $a$, it means they have weak of vocabulary. Those errors are caused by students mother tongue toward the acquisition of the new structure.

With regard to such errors, on the other hand, it is difficult for Indonesian students to use correct grammar in English. This is mostly a problem because the students'utterances are influenced by their mother tongue toward the acquisition of the new structure. However, the students in vocational high school level are still weak in English, especially in their writing skill. They still seem to commit 
errors in all aspect of language. Errors in writing such as tenses, prepositions and lack of vocabulary are the most common and frequent type of errors that are committed by the students. The students usually face difficulties in learning the grammatical aspects of the Target Language (TL), such as in subject-verb agreement, the use of preposition, articles and the use of correct tense even error in writing a sentence with has no meaning. Zhang (2011) said that:

errors can be seen clearly in the learners' written performance that the students are bound to encounter would be weak vocabulary, inappropriate use of grammar in sentence etc.

In other words, there are other related previous studies which lied the research on narrative writing composition that confirm such a view. Wee (2009) investigated sources of errors: an interplay of interlingual influence and intralingual factors. She conducted a research in three different types of compositions: a) a narrative composition b) a descriptive essay; and c) an expository essay. The finding indicated that errors of misformation were the highest consisting of $63.4 \%$, followed by those of omission at $29.0 \%$, addition at $7.6 \%$ and those of ordering at $0.1 \%$. Then, by essay type, the highest percentage of errors was found in the narrative essay at $40.3 \%$ followed by the descriptive essay at $32.7 \%$ and the expository essay at $27.0 \%$. For the tense category, the highest percentage of errors was in the past tense at $37.6 \%$ followed by the present tense at $33.7 \%$, future tense at $21.5 \%$ and other verb forms at $7.3 \%$. For the explanation for errors made, it shows that there were 153 omission errors in the narrative essays consisting of $27.2 \%$ of the total 563 errors found in the 50 narrative essays. The addition errors in the narrative essays consisted of 59 errors, making up $10.5 \%$ of the total errors found. There were 351 misformation errors found in the narrative essays which consisted of $62.3 \%$ of the total 563 errors found in this essay type. In the descriptive essays, there were 457 errors found, out of which 153 were omission errors. There were 282 misformation errors in the descriptive essays with 49 SVA errors making up $20.4 \%$ of the errors. There was a total of 378 errors found in the expository essay of which 99 errors or $26.2 \%$ were errors of omission. For the recommendation, the teacher should explain the use of each tense based on time orientation: present, past, future and future in the 
past. A useful way to teach the different tenses is to use an imagery biography which gives details of someone's past, present and future life. Error correction is also a useful technique to teach grammatical rules to students by drawing students' attention to the errors made.

Next, Hau Tse (2014) focused on a case study of grammatical errors made by malaysian students. The findings revealed a total of 797 errors. Six significant errors occurred in the sample were a) singular/plural noun; b) articles; c) prepositions; d) adjective/noun/adverb; e) subject-verb agreement; and f) tenses. The are various ways to cope with errors, for instance, 'process writing' and 'peer correction; thay are recommended to help the learners avoid making errors.

Moreover, Mohammed (2016) investigated error analysis: a study on grammatical errors in the writings of iraqi efl learners. The result of the study showed that the common types of grammatical errors in the subjects' writing include verb tense and form, subject-verb agreement, articles, prepositions, misuse of pronouns, misuse of plurals and misuse of auxiliaries. The most frequent grammatical errors committed in syntax and morphology were verb tense and form errors, which took up $98(22 \%)$ of the totality errors. Whereas, the second high level errors were prepositions, which were covered 88 (19\%). Also articles errors were a high committed errors, which accounted for $81(18 \%)$ of the totality. Furthermore, misuse of plural errors were covered 67 (15\%) of the total errors in the subjects writing. In syntax errors subject-verb agreement took up 61 $(13 \%)$ of the totality errors. Whereas, it can be seen that the frequency and the percentage of misuse of pronouns errors were less frequent, which covered 34 (7\%) of the totality errors. Lastly, misuse of auxiliaries errors appeared the least frequently committed errors, which took up $27(6 \%)$ of the totality errors in the subjects writing.

Thus, this current study is different from those previous studies due to this research is focused on errors in writing Narrative text and identify the types of errors then the researcher uses linguistics category and surface strategy taxonomy to classify the types of errors and focuses to identify the types of lexical errors, syntactical errors and discourse oerrors; depicts the frequency of each type of 
errors; makes clear the frequency of each the most dominant errors; then investigates the causes of errors.

As a result, the objective of this study is three folds: (1) to identify the types errors in the students' writing; (2) to know the frequencies of each type of errors; and (3) to investigate the causes of errors.

\section{RESEARCH METHOD}

This research applies descriptive qualitative method. Sugiyono (2013: 205) states "the qualitative research is a research which yields the descriptive data in the form of written or oral words from observing people and behavior". The data of this research are the sentences that contain of errors taken from students' writing. The erroneous sentences are taken from 15 pieces of students' writing from class XI APH 1, there are 15 pieces from class XI APH 2 students, and 15 pieces from class XI APH 3. The total sources of data are 45 students' English narrative text writing by students of class XI in SMKN 4 Surakarta academic year $2014 / 2015$.

For the data collection technique, the researcher uses elicitation method. $\mathrm{He}$ prepares some documents and complements. The researcher gets the data of the students' writing through one source: the writing narrative task. The advantage of collecting data by asking the research participants to do a writing task is obtaining highly authentic data, but they would write the free composition of narrative text in the same topic and it is conducted in the same level, then sitting in a classroom. The researcher collects the data two times and the distance of the time is two weeks and in the same time.

Then, In analyzing the data of errors, the researcher uses error analysis method based on Corder as quoted by Shridar in Fauziati (2009: 136). The following steps to conduct an error analysis research as follows:

\section{Identification of Errors}

In this step, the researcher studied acquired data and tried to find out the grammatical errors by underlying errors. the researcher tried to analyze the data as objective as possible.

a. Classification of Errors 
Once the errors have been identified, the researcher classified them into 4 categories, they are:1) errors of omission; 2) errors of addition; 3) errors of misformation; and 4) errors of misordering.

\section{b. Calculation of Errors}

In this step, the researcher calculated the errors in order to know how frequent these errors in writing narrtive texts that have been done by students of class XI APH 1, XI APH 2, and XI APH 3 in SMKN 4 Surakarta and to know the dominant errors that occured in the students' writing. The error classification will be based on lingustics category by James (1998) and the surface strategy taxonomy by Dulay et.al (1982). Then to count category of errors and the dominant errors, the researcher uses formula based on Bungin (2005: 171) in Srikandi (2009). The following formula is:

$$
P=\frac{F}{N}(x 100)^{\%}
$$

Where:

$\mathrm{P}=$ percentage of the category errors

$\mathrm{F}=$ frequency of error occured

$\mathrm{N}$ = number of cases (total frequent/total individual)

c. Drawing a Conclusion

The last step would be drawing a conclusion based on the analysis. In this step, the researcher has to make a valid conclusion in the form of a brief description of the errors.

\section{RESEARCH FINDING AND DISCUSSION}

The researcher finds the total number of errors about 541 errors which are committed by grade XI students. Then, it is divided into three categories, namely; lexical errors are 140 erroneous sentences, syntactical errors are 348 erroneous sentences, and discourse error are 53 erronous sentences.

\section{Types of Errors Found in the Students' Writing}


The Researcher finds the errors based on the theory of linguistic category and surface strategy taxonomy which are appropriate to find the error toward the students' writing. The data are taken from students in grade XI of SMKN 4 Surakarta.

\section{a. Lexical}

The errors in lexical occurs when English words are chosen incorrectly by the learners. There are many patterns of words choice such as word spelling, wrong selection word, close word, separate words and others.

1) Wrong Spelling Words

The student still produces erroneous in vocabularies, sometimes the student spells the words incorrectly. Student also omits or adds some items of letter in a word so that the word has no meaning. For example:

But everyting changes when mother past away and father Kirana married with Sulastri, this is start bad Kirana. (wrong)

But everything changed when the mother passed away and Kirana's father married with Sulastri, this is bad start for Kirana. (correct)

2) Wrong selection words

Wrong selection word is the process of choosing the wrong word to complete sentence, the students choose other word instead of the correct word to complete the sentence such as student writes "past away" instead of "passed away", they want to write "lived" but they write "life". The datum of error can be seen below:

Once upon a time, there life the little girl the name Snow White. (wrong)

Once upon a time, there lived a little girl named Snow White. (correct)

\section{b. Syntactical Errors}

Syntax errors occur during the parsing of input code, and are caused by grammatically incorrect statements. It is occured when foreign language learners have lack of grammar knowledge and their mental process are weak about the target language (TL) toward their utterance or writing production.

\section{Verb}

Verb is function as the complement to make sentence, without using verb people can not understand the meaning of a sentence.

Premise Journal Vo. 5 No. 2 October 2016, ISSN online: 2442-482x ISSN printed: 2089-3345 
a) Omission Verb

The student commits the o error on his/her writing by missing the verbs in the sentences. It is occured because he/she does not know the structure of sentences then he/she omits verbs in his/her sentences or he/she also ignores the rule of English structure. For example:

Once upon a time, there live a princess that [...] a long hair and blue eyes. (wrong)

Once upon a time, there lived a princess that had a long hair and blue eyes. (correct)

b) Omission v-ing after Preposition for

The use of the preposition for is called a "verb-preposition" pair and allow the preposition to modify the verb. It is aknowledged that the foregoing description is at odds with our usual understanding of parts of speech and what they are supposed to be doing. In this case, student makes error in the use of v-ing after the preposition for. He/she misses the final -ing in the verb. For example:

Someday a mouse deer need a fruits for eat [..]. (wrong)

Someday a mouse deer need a fruit for eating. (correct)

c) Addition Unnecessary Verb

In this case, the student adds more than one verb in sentence that one of the verb is unnecessary because it is enough to use the suitable one, and also he/she adds more than one verb in one sentence, it is become incorrect English form. For example:

But went klenting kuning want to follow go to competition... (wrong)

But when klenting kuning wanted to follow the competition... (correct)

d) Using Simple present Tense refers to Simple past

In this case, the student still uses simple present tense verb in their writing. It seems that he/she ignores the rule of grammar in English or he/she has not reached the material yet, so that he/she still uses simple present tense instead of simple past tense form. For example:

Some years ago, dayang sumbi fall in love with sangkuriang. (wrong)

Some years ago, dayang sumbi fell in love with sangkuriang. (correct)

e) Use simple future instead of simple Past future 
The student makes error in the use of past future tense. He/she still uses simple future in making narrative text. For example:

He plant a melons and hope can grow well. (wrong)

He planted a melon and hope it could grow well. (correct)

f) Using Irregular Past Verb Tense after to Infinitive

In this case, the student thinks that if the text is a story it must use verb 2 whatever itself. He/she just knows and remembers that narrative uses verb 2, but he/she does not know that if the sentence includes to infinitive as the verb, then the verb used in the sentence must be in base verb form not in past form. For example:

Beast permit he to went home. (wrong)

The beast permitted him to go home. (correct)

g) Addition Final ed after to Infinitive

After checking the student's writing, then the researcher finds erroneous sentence that the student puts final -ed in the verb after to infinitive. For example:

Sunddenly, the fairy Godmother arrived to helped Cinderella. (wrong)

Suddenly, the fairy Godmother arrived to help Cinderella. (correct)

h) Addition v-ing after to Infinitive

In English however if a verb uses to infinitive the verb followed by the to infinitive is base verb not adding by final -ing. In this case, the student writes error in the use of to infinitive. For example:

The prince invite Cinderella to dancing with him. (wrong)

The prince invited Cinderella to dance with him. (correct)

i) Addition Double Marking Verb

In this case, the student makes error in putting different verb in one sentence in his/her writing. For example:

Then she inside and don't saw people in the cottage. (wrong)

Then she came in and didn't see any people in the cottage. (correct)

\section{To be}


To be is used to indicate the identity of a person or thing, used to describe the qualities of a person or thing, and used to indicate the condition of a person or thing.

a) Omission to be

In this case, student omits the use of to be before verb and adjective. The student often makes error in the use of to be. When he/she writes a sentence, it seem that he/she misses about the use of to be. It is occured in the use of past continuos tense and when he/she shows an adjective. For example:

The prince_falling in love with her. (wrong)

The prince was falling in love with her. (correct)

b) Addition to be

In this case, the student still does not understand about the use of to be. For example:

Cinderella lived was happily with her father and mother until her mother died. (wrong)

Cinderella lived happily with her father and mother until her mother died. (correct)

\section{Noun}

In this research, the researcher finds some students make error in the use of noun by omitting the use of s/es in plural noun and add final $-\mathrm{s}$ in the singular noun.

a) Omission s/es in the Use of Plural Noun

The plural form of most nouns is created simply by adding the final -s/-es. Words that ends in ch, $\mathrm{x}, \mathrm{s}$, or s-like sounds however will require an -es for the plural. For example, boxes mean more than one box. In other case, with words that end in a consonant and a y, it needs to change to $\mathrm{y}$ an $\mathrm{i}$ and add es. While, another case just need to add final $-\mathrm{s}$ after the words end with consonant. This case occurs in the students' sentence because the student sometimes transfers his/her native language structure into English structure or he/she ignores the English grammatical rule because Indonesia has no tense marker like English.

Father remarried again with a woman who has 2 daughter. (wrong) Father remarried again with a woman who has 2 daughters. (correct) 
b) Addition s in Singular Noun

Addition final $-\mathrm{s}$ in singular noun means putting unnecessary final -s for plural form in singular noun form. In this case, student commits error in adding final s in singular form. For example:

He plant a melons and hope can grow well. (wrong)

He planted a melon and hope it could grow well. (correct)

\section{Sentence Construction}

Sentence construction is the order and arrangement of the clauses in a sentence, which is a group of words that express a complete thought. Each of sentence can be identified by the number and types of clauses found within them.

a) Omission Article

Using article in English seems very hard for the student since it has various usages. As a result, when student is not sure whether to use an article for a certain thing, he/she often overgeneralizes it or omits it.

One day in [...] village lived_happy family. (wrong)

One day in $a$ village lived a happy family. (correct)

b) Addition Unnecessary Article

Addition unnecessary article occurs when students use it in constructing English sentences. In this case, student makes error in the use of article. For example:

....she wanted to marry $a$ prince Liam. (wrong)

....she wanted to marry prince Liam. (correct)

c) Wrong Article

Sometimes, the use of article in English leads the student into errors. The use of indefinite article a/an makes the student confused which he/she should appear in a sentence. For example:

Once upon a time, lived $a$ old man. (wrong)

Once upon a time, lived an old man. (correct)

d) Wrong Subject Pronoun

A subject pronoun is a personal pronoun that is used as the subject of a verb. Subject pronouns are usually in the nominative case for languages with a 
nominative-accusative alignment pattern. In this case, the student makes error in the use of subject pronoun.

The next day, her wake up ... (wrong)

Next day, she wake up ... (correct)

e) Wrong Object Pronoun

Using objective pronoun seems to be problematic for the student. the error occur when the student make error in the use of subject pronoun instead of object pronoun.

Many people helped she to made fire and sounds of chicken. (wrong)

Many people helped her to make fire and sounds of chicken. (correct)

f) Wrong Possessive Pronoun

The student uses the pronoun improperly. It is because he/she has lack of information. For example:

They name is Onion and Garlic. (wrong)

Their name was Onion and Garlic. (correct)

\section{Discourse}

In linguistics, discourse refers to a unit of language longer than a single sentence. Discourse Errors beyond the sentence level, for example, inappropriate refusal and incorrect topic.

\section{a. Generic Structure}

In this point, student makes error in generic structure such as give incomplete information in orientation, he/she does not appear the place where the story begins. For example:

Once upon a time, there life the litle girl the name Snow White. Snow White life with her aunt and her uncle because her parents was dead. ( student does not appear the place where the story begins)

b. Reference

Personal reference is two linguitics elements are related in what they refer to. e.g. $\underline{E k o}$ lives near the park. $\underline{H e}$ often goes there. In this case, the student makes error in referring subject of personal reference.

Sulastri gave neakle to Kirana, Kirana so funny.(wrong)

Sulastri gave neakle to Kirana and she was so funny.(correct) 
c. Wrong Selection Conjunction

In this point the student uses wrong conjunction when he/she makes a sentence. For example:

Malin go to city after in city he became a success people in the city.(wrong) Malin went to the city then he became a success person in the city. (crrect)

\section{Frequency Each Type of Overgeneralization Error}

In this part, the researcher counts the frequency of error in order to get the percentage of each type of errors. Then, after counting the data, the researcher gets 541 data errors make by students. moreover, it is divided into three categories types of error. They are lexical errors, syntactical errors, and discourse errors. 140 data errors or $25,88 \%$ belong to lexical errors, 348 data errors or $64,33 \%$ belong to syntactical errors, and 53 data errors or $9,80 \%$ belong to discourse errors. those errors are converted into diagram below.

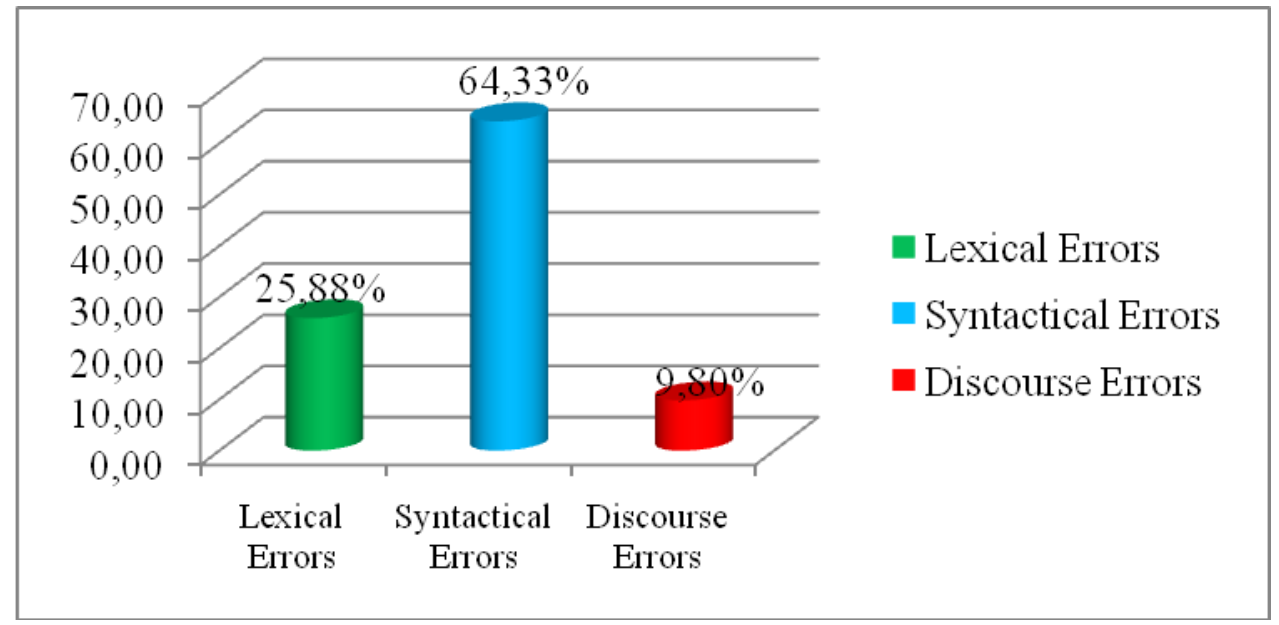

Figure 1. Percentage of Error Types

From the figure above, then the researcher divided the kinds of errors to be 24 errors it can be seen in the table below.

Table 1 The Percentage of Each Error based on Lexical, Syntax, and Discourse

\begin{tabular}{|c|l|c|c|}
\hline No & \multicolumn{1}{|c|}{ Type of Errors } & Number & Percentage \\
\hline $\mathbf{1}$ & I. Lexical Error & $\mathbf{1 4 0}$ & $\mathbf{2 5 , 8 8 \%}$ \\
\hline & 1. Wrong Spelling Words & 56 & $10,35 \%$ \\
& 2. Wrong Selection Words & 84 & $15,53 \%$ \\
\hline $\mathbf{2}$ & II. Syntactical & $\mathbf{3 4 8}$ & $\mathbf{6 4 , 3 3 \%}$ \\
\hline
\end{tabular}




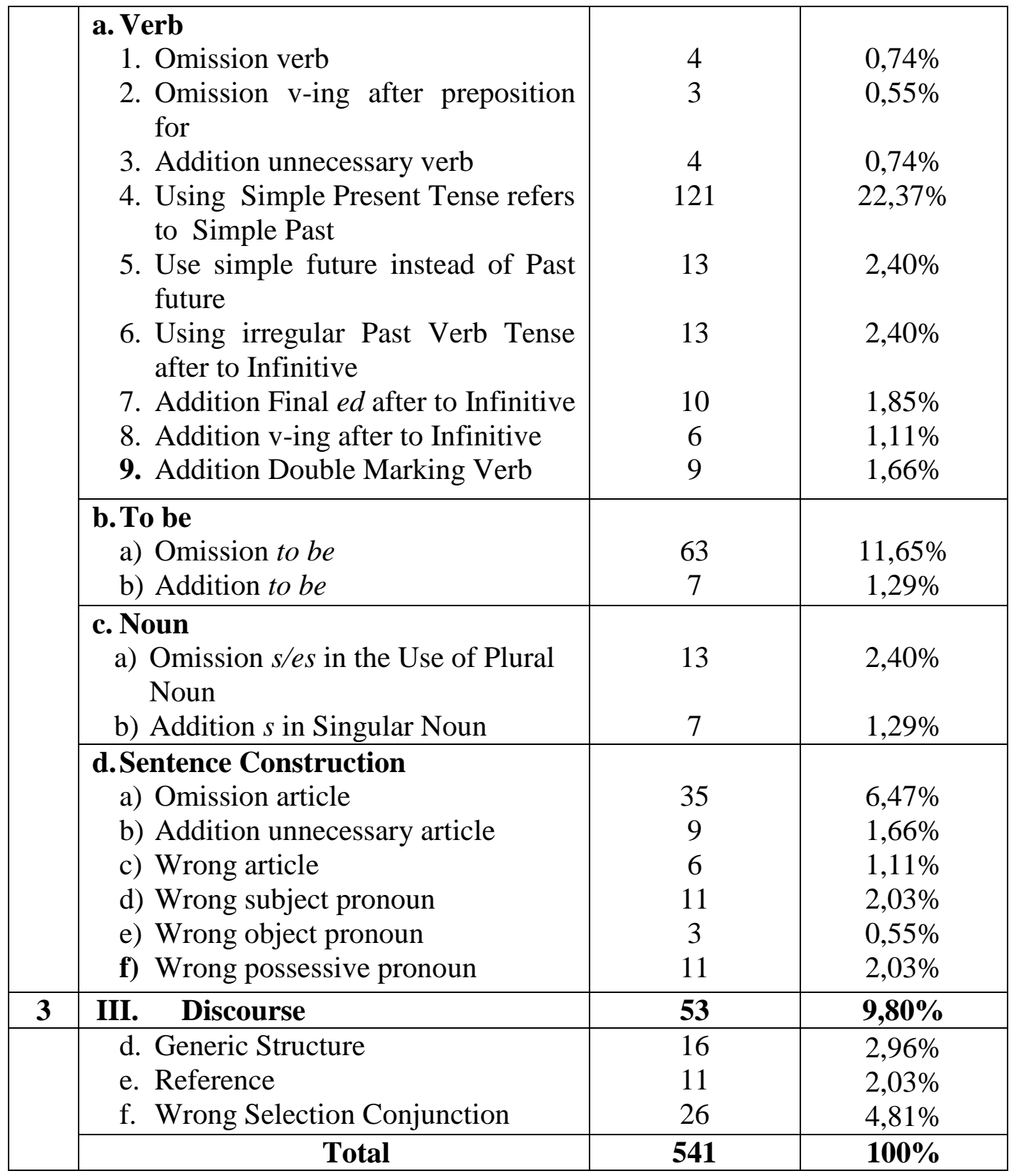

From each kind of errors above, it implies that the most dominant error is in syntactical errors which is involved 348 errors or $64,33 \%$, but for the subject errors the highest dominant error is in using simple present tense refers to simple past (121 errors or $22,37 \%)$.

\section{The Causes of Errors}

After analyszing the causes of errors, then the researcher counts the data to know the percentage of each type error causes. The result of calculations can be seen in the pie chart below. 


\section{Percentage Causes of Errors}

$\begin{array}{ll}\square \text { Overgeneralization } & \text { Incomplete Application of Rules } \\ \square \text { False Concepts Hypothesized } & \square \text { Ignorance of Rule Restriction }\end{array}$

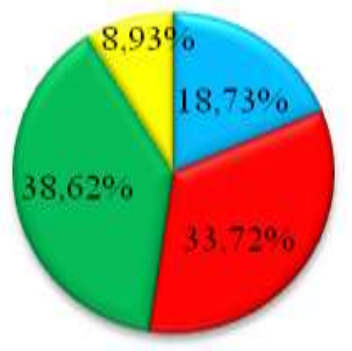

Figure 2 Causes of Errors

The pie chart above shows the number and percentage of error causes. First, Most of the students make error in false concepts hypothesized. It may be due to the poor gradation of teaching items of grammar then many students get confused and can not differentiae the items of grammar. It is because the students are not paying attention in the difference between items. Second, many students commit errors in incomplete application of rules. It is because students do not know the whole rule or pattern of grammar correctly. Third, students hold errors in overgeneralization. It is occured due to the students create a new pattern of false structure on their basic experience of other structure in target language. The last, students make errors in ignorance of rule restriction. In this case, students ignore the rule of grammar in the context where they do not apply in target language.

\section{CONCLUSION}

Based on the analysis in the research finding, it can be concluded that errors do occur in the production of narrative text committed by students in grade XI of SMKN 4 Surakarta. There are three types of errors namely lexical, syntactical and discourse error. the types of errors have twenty four categories of errors. The Premise Journal Vo. 5 No. 2 October 2016, ISSN online: 2442-482x ISSN printed: 2089-3345 
errors can be categorized as follows: wrong spelling words (10,35\%), wrong selection words $(15,53 \%)$, omission verb $(0,74 \%)$, omission v-ing after preposition for $(0,55 \%)$, addition unnecessary verb $(0,74 \%)$, using simple present tense refers to simple past $(22,37 \%)$, use simple future instead of past future $(2,40 \%)$, using irregular past verb tense after to infinitive $(2,40 \%)$, addition final ed after to infinitive (1,85\%), addition v-ing after to infinitive (1,11\%), addition double marking verb $(1,66 \%)$, omission to be $(11,65 \%)$, addition to be $(1,29 \%)$, omission s/es in the use of plural noun $(2,40 \%)$, addition $\mathrm{s}$ in singular noun $(1,29 \%)$, omission article $(6,47 \%)$, addition unnecessary article $(1,66 \%)$, wrong article $(1,11 \%)$, wrong subject pronoun $(2,03 \%)$, wrong object pronoun $(0,55 \%)$, wrong possessive pronoun $(2,03 \%)$, generic structure $(2,96 \%)$, reference $(2,03 \%)$, wrong selection conjunction $(4,81 \%)$. The most dominant error is in syntactical error i.e. using simple present tense refers to simple past with the percentage $22,37 \%$. Those errors are caused by four aspects, they are incomplete application of rules, ignorance of rule restrictions, dan false concept hypothesized. Most of the students make error in false concepts hypothesized. It may be due to the poor gradation of teaching items of grammar then many students get confused and can not differentiae the items of grammar. 


\section{REFERENCES}

Dulay,Heidi.,Burt,Marina.,Krashen,Stephen. (1982). Language Two. New York Oxford: Oxford University Press.

Fauziati, Endang. (2009). Readings on Applied Linguistics: A Handbook for Language Teacher and Teacher Researcher. Surakarta: Era Pustaka Utama.

Hau Tse, Andrew Yau. (2014). A Case Study of Grammatical Errors Made by Malaysian Students. International Journal of Science Commerce and Humanities Volume No 2 No 5. Universiti Tunku Abdul Rahman Faculty of Arts \& Social Science, Perak Campus 31900 Kampar: Malaysia.

James, Carl. (1998). Error in Language Learning and Use: Exploring Error Analysis. London: Routledge.

Mohammed, Mohanad Qasim. (2016). Error Analysis: A Study on Grammatical Errors in the Writings of Iraqi EFL Learners. EUROPEAN ACADEMIC RESEARCH Vol. III, ISSN 2286-4822. www.euacademic.org.

Srikandi, Cut Novia. (2009). Borrowing in the Translation of D.H Lawrence's Lady Chatterley's Lover into Indonesian. Thesis. University of North Sumatra.

Sugiyono. (2013). Penelitian Kuantitatif, Kualitatif, dan R\&D. Bandung: Alfabeta.

WEE, Roselind. (2009). Sources of Errors: An Interplay of Interlingual Influence and Intralingual Factors. European Journal of Social Sciences Volume 11, Number 2. Universiti Teknologi Mara (UiTM). Jalan Meranek 94300 Kota Samarahan, Sarawak, Malaysia.

Zhang, Meng. (2011). Error Analysis and Interlanguage. Focus Vol.1, pp.85-93. 